\title{
Lithium, an old friend and a forgotten enemy
}

\author{
(D) Cátia Figueiredo ${ }^{1}$ \\ Joana Lemos ${ }^{1}$
}

1. Department of Internal Medicine, Centro Hospitalar Tondela-Viseu, E.P.E., Viseu, Portugal.

http://dx.doi.org/10.1590/1806-9282.66.12.1625

\section{SUMMARY}

INTRODUCTION: Nephrogenic diabetes insipidus (DI) is a polyuric and polydipsic syndrome and can have multiple causing factors.

CASE DESCRIPTION: A 69-year-old woman with bipolar disorder medicated with lithium $400 \mathrm{mg}$ for 12 years on a daily basis. The patient was admitted, after psychiatric decompensation, with hypernatremia unresponsive to hypotonic iv fluids. The diagnosis of DI was made with high plasmatic osmolality measurement, low urine osmolality, and high levels of antidiuretic hormone. Full clinical recovery was possible with lithium suspension, hydration, and chlorthalidone.

DISCUSSION: Although frequently used in the past, Lithium $(\mathrm{Li})$ is nowadays rarely used in clinical practice for prolonged treatments because of its potentially devastating side effects. Clinicians must be aware of those side effects in order to prevent organ damage, mainly in patients with severe bipolar disease and precarious response to alternative treatments.

KEYWORDS: Bipolar disorder. Lithium. Diabetes insipidus, nephrogenic.

\section{INTRODUCTION}

Diabetes insipidus (DI) is a polyuric polydipsic syndrome that can be of central or nephrogenic origin. Patients with DI have a urinary output of more than $50 \mathrm{~mL}$ per $\mathrm{Kg}$ in 24 hours and usually consume more than $3 \mathrm{~L}$ of water per day ${ }^{1}$. Nephrogenic DI is associated with the inability of the kidney to respond to the neuropeptide vasopressin. Vasopressin is secreted in the posterior hypothalamus (paraventricular and supraoptic nuclei) in response to hypovolemia or osmolality shifts and acts in the receptor $\mathrm{V} 2$ of the principal cells of the conducting duct, allowing the reabsorption of water through the regulation of the aquaporin 2 water channel (AQP2) 2 .

Nephrogenic DI can be congenital, detected in the early stages of life, or acquired, associated with drugs, systemic disease, or electrolyte abnormalities ${ }^{2}$.

Lithium was once one of the most used and efficacious treatments of type 1 bipolar disease, but the emergence of serious side effects concerning nephrotoxicity led to its obliviation. Nephrogenic DI associated with $\mathrm{Li}$ usually appears after longer periods and with higher cumulative doses. Other factors include female gender, age, and other risk factors for chronic kidney disease ${ }^{3}$. Renal side effects are mostly associated with the action in the principal cells of the distal tubules and collecting ducts. Li enters through the epithelial sodium channel in the cell and accumulates there, interfering with the traffic of AQP2 and allowing the loss of a great quantity of water through dilute urine and leading to the clinical picture of polyuria, polydipsia, and hypernatremia ${ }^{4}$.

DATE OF SUBMISSION: 27-|Un-2020

DATE OF ACCEPTANCE: 27-Jul-2020

CORRESPONDING AUTHOR: Cátia Castanheira Figueiredo

Centro Hospitalar Tondela-Viseu - Rua Senhora da Graça n 1, RE esq, Repeses, Viseu, Portugal

Tel: +351 32 96414-7134

E-mail: cati.castanheira@gmail.com 


\section{DESCRIPTION}

A 69-year-old woman with a history of bipolar disorder with 12 years of evolution, chronically medicated with clozapine $100 \mathrm{mg}$ (1/2id), carbamazepine $200 \mathrm{mg}$ (2id), lithium 400mg (2id), lorazepam 1mg (3id), memantine 20mg (id), and haloperidol (20 to 30 drops in SOS). Irrelevant family history. Admitted to the psychiatric department due to behavioral decompensation. Polyuria and polydipsia had been reported in the previous 6 months, with normoglycemia. Due to maniac behavior, risperidone $25 \mathrm{mg}$ IM was initiated every other week. The routine analysis detected hypernatremia $(153 \mathrm{mEq} / \mathrm{L})$ and she initiated iv fluids with hypotonic NaCl at $0,45 \%, 1 \mathrm{~L}$ per day. The paranoid behavior remained, and risperidone was raised to 50mg IM. Despite hypotonic fluid infusion, hypernatremia became more severe $(172 \mathrm{mEq} / \mathrm{L})$, with associated hyperchloremia $(135 \mathrm{mEq} / \mathrm{L})$. At the examination, she had altered mental status although easily aroused, dehydration, diuresis of 4L per day, without focal neurological deficits. No other remarkable points. A head CT scan did not show any relevant changes and a MRI was not performed. Analytically, there was an elevated plasma osmolarity of $331 \mathrm{mOsm} / \mathrm{L}$ (280-301 mOsm/L), with a low urinary osmolarity $139.7 \mathrm{mOsm} / \mathrm{L}$ (300-900 $\mathrm{mOsm} / \mathrm{L}$ ), and a low urinary sodium $44.4 \mathrm{mEq} / \mathrm{L}$ (54$150 \mathrm{mEq} / \mathrm{L})$. The antidiuretic hormone in the blood was $11,3 \mathrm{pg} / \mathrm{mL}$ (normal $<6.7 \mathrm{pg} / \mathrm{mL}$ ), and urine osmolality did not increase with the administration of desmopressin, confirming the diagnosis of nephrogenic diabetes insipidus. Considering a probable relationship with lithium, its chronic intake was suspended, and neuroleptics were reduced. Hydratation was performed by nasogastric tube until recovery of mental status and thereafter with a liberal intake of fluids, chlorthalidone $25 \mathrm{mg}$ id was introduced. There was a normalization of the ionogram and full recovery of previous functional status with physical rehabilitation. After six months of therapy, chlorthalidone was suspended with no DI relapse.

\section{DISCUSSION}

The diagnosis of DI is made through a laboratory evaluation that includes serum and urine osmolality as well as sodium and serum levels of vasopressin. The water deprivation test is still used to diagnose DI in cases when the serum osmolality is above $300 \mathrm{mosm} / \mathrm{Kg}$. The response to the administration of D-amino D-arginine vasopressin allows differentiating the nephrogenic type from the central $\mathrm{DI}^{2}$. The diagnostic algorithm accuracy is only around $70 \%$, which led to the proposal of a direct test that includes the measure of serum vasopressin levels after osmotic stimulation failed to enter clinical practice. There is increasing evidence for new markers such as copeptin that likely increase the accuracy of the etiology of the polyuric polydipsic syndromes ${ }^{1,5}$. Imaging tests like MRI do not appear to have a role in the diagnosis of $\mathrm{DI}^{\mathbf{1}}$.

Nephrogenic DI associated with lithium is seen rarely nowadays since its use as a mood stabilizer decreased dramatically. The treatment requires stopping the therapy, hydration, and sometimes thiazidic diuretics to restore the hydric balance by increasing the amount of sodium and water reabsorbed in the proximal tubules ${ }^{2,3}$. Other possibilities are the prostaglandin synthesis inhibitors and acetazolamide, with the last not approved yet ${ }^{2}$.

The prognosis is usually good when the cessation of the Li therapy is tolerated by the patient, and nephrogenic DI can sometimes completely resolve $\mathrm{e}^{2,3}$.

\section{CONCLUSION}

The diagnosis of polyuric polydipsic syndromes is still a challenge in clinical practice, although it seems to be evolving to more accurate techniques. Although $\mathrm{Li}$ is now rarely used in clinical practice, clinicians must be aware of the possible side effects of prolonged treatments and ideally anticipate their appearance in order to prevent organ damage.

\section{Author's Contribution}

All authors have contributed equally to the work.

\section{Learning points}

- Lithium therapy, despite its great effectiveness, is now rarely used in clinical practice due to its side effects;

- Whenever there is a suspicion of a polyuric polydipsic syndrome, all causes must be excluded since nephrogenic DI can have many causes;

- Early recognition and management of this syndrome can prevent life-threatening complications. 


\section{RESUMO}

INTRODUÇÃO: O diabetes insípido nefrogênico faz parte das síndromes poliúricas polidipsicas e pode ter múltiplos fatores causais.

CASO CLínico: Mulher de 69 anos, com doença bipolar medicada com lítio 400 mg por dia durante 12 anos. A doente foi internada, após descompensação da doença bipolar, por hipernatremia não responsiva a fluidoterapia hipotônica endovenosa. O diagnóstico de DI foi realizado com base na elevação da osmolaridade plasmática, baixa osmolaridade urinária e níveis elevados de hormona antidiurética. Verificou-se recuperação clínica completa com suspensão do lítio, hidratação e clorotalidona.

DISCUSSÃo: Apesar do seu uso frequente no passado, o lítio (Li) é hoje em dia raramente utilizado na prática clínica por períodos prolongados pelos seus efeitos potencialmente devastadores. Os médicos devem ter em conta os potenciais efeitos secundários de forma a prevenir lesão de órgão em doentes com doença bipolar de difícil controle com outra terapêutica.

PALAVRAS-CHAVE: Transtorno bipolar. Lítio. Diabetes insípido nefrogênico.

\section{REFERENCES}

1. Christ-Crain M. New diagnostic approaches for patients with polyuria polydipsia syndrome. Eur J Endocrinol. 2019;181(1):R11-R21.

2. Kavanagh C, Uy NS. Nephrogenic diabetes insipidus. Pediatr Clin North Am. 2019;66(1):227-34.

3. Davis |, Desmond M, Berk M. Lithium and nephrotoxicity: a literature review of approaches to clinical management and risk stratification. BMC Nephrol. 2018;19(1):305.
4. Davis J, Desmond M, Berk M. Lithium and nephrotoxicity: unravelling the complex pathophysiological threads of the lightest metal. Nephrology (Carlton). 2018;23(10):897-903.

5. Ranieri M, Di Mise A, Tamma G, Valenti G. Vasopressin-aquaporin-2 pathway: recent advances in understanding water balance disorders. F1000Res. 2019;8:F1000 Faculty Rev-149. 